\title{
Milksolids production from cows grazing perennial ryegrass containing AR1 or wild endophyte
}

\author{
S. J. BLUETT, E. R. THOM, D. A. CLARK, K. A. MACDONALD and E. M. K. MINNEÉ \\ Dexcel, P B 3221, Hamilton \\ stephanie.bluett@dexcel.co.nz
}

\begin{abstract}
A 3-year farmlet experiment was carried out at Dexcel, Hamilton to evaluate the effects of AR1 (no lolitrem B or ergovaline production) and wild (standard or natural) endophyte-infected ryegrass on milksolids production and cow health. Two farmlets (7 ha each) were managed as self-contained systems with cows rotationally grazing treatment paddocks from September 2000 to May 2003. In the 2000/2001 milking season, cows grazing AR1 endophyteinfected ryegrass produced $10 \%$ more milksolids than those grazing wild endophyte-infected ryegrass (247 versus $224 \mathrm{~kg} / \mathrm{cow}, \mathrm{SED}=8.4, \mathrm{P}<0.01)$. Treatment differences were smaller and not statistically significant in the second and third milking seasons. A combined analysis of the 3 milking seasons data, showed a significant milksolids production advantage to cows grazing AR1 endophyte-infected ryegrass pastures (318 versus $292 \mathrm{~kg} / \mathrm{cow}, \mathrm{SED}=9.2$, $\mathrm{P}<0.01)$. Milk composition was similar in all seasons. Milksolids production averaged over 3 milking seasons was significantly higher in cows grazing AR1 endophyte-infected ryegrass in summer (110 versus $103 \mathrm{~kg} / \mathrm{cow}, \mathrm{SED}=2.9, \mathrm{P}<0.01)$ and autumn $(50$ versus $44 \mathrm{~kg} / \mathrm{cow}, \mathrm{SED}=2.1, \mathrm{P}<0.01)$, and showed a similar effect in spring (157 versus $147 \mathrm{~kg} / \mathrm{cow}$, $\mathrm{SED}=5.5, \mathrm{P}<0.1$ ). Ryegrass staggers occurred in cows grazing wild endophyte-infected pastures in January 2001 , coinciding with the highest concentrations of lolitrem B over the 3 seasons $(>3.5 \mathrm{mg} / \mathrm{kg})$. Cow temperatures, respiration rates and plasma prolactin concentrations were seldom affected by endophyte treatment. Annual pasture production was similar across AR1 and wild endophyte-infected ryegrass farmlets from September 2000 to September 2001 (14.7 versus $14.4 \mathrm{t} \mathrm{DM} / \mathrm{ha}, \mathrm{SED}=1.11, \mathrm{NS})$ and from September 2001 to September 2002 (14.1 versus 12.9 t DM/ha, SED = 0.73, NS). AR1 endophyte-infected ryegrass pastures remained free of contamination from wild endophyte-infected ryegrass for at least 3 years after establishment, as indicated by low concentrations of lolitrem $B$ detected in pasture samples.
\end{abstract}

Keywords: dairying, heat stress, Lolium perenne, Neotyphodium lolii, novel endophytes, pasture production, prolactin, ryegrass staggers

\section{Introduction}

Most perennial ryegrass (Lolium perenne) plants in New Zealand pastures are infected with a naturally occurring fungal endophyte (Neotyphodium lolii). This perennial ryegrass/endophyte association produces compounds called alkaloids that vary in concentration over the year. Some alkaloids enhance the persistence and productivity of ryegrass pastures by protecting them from insect attack, such as peramine which provides protection against Argentine stem weevil (Listronotus bonariensis) and ergovaline which protects against black beetle (Heteronychus arator). However, some alkaloids may affect animal performance and health when consumed in too high a concentration. These include lolitrem B, which causes ryegrass staggers, and ergovaline which has been associated with increased heat stress in sheep (Fletcher et al. 1999).

When renovating perennial ryegrass pastures, farmers now have the opportunity to select cultivars with no endophyte, the wild (standard or natural) endophyte, or a new endophyte selection called AR1. AR1 does not produce the toxic alkaloids lolitrem B or ergovaline, but still produces the insect deterrent peramine (Tapper \& Latch 1999). Grazing trials have shown that ryegrass containing AR1 endophyte improved sheep liveweight gains compared to those on wild endophyte (Fletcher 1999). Bluett et al. (2001b) showed from 3 short-term experiments at Dexcel that cows grazing AR1 endophyte-infected ryegrass in autumn produced $8 \%$ more milk than those grazing wild endophyte-infected ryegrass $(\mathrm{P}<0.1)$, with similar milk yields during spring and summer. This paper reports a farmlet experiment where the cows were continuously stocked on their treatments for 3 years to determine the effects of AR 1 and wild endophyte on milksolids production and cow health.

\section{Materials and methods \\ Pastures}

The experiment was conducted on two 7 ha farmlets on Scott Farm, Dexcel, Hamilton. Seven 1 ha paddocks were randomly allocated to each farmlet balanced for soil type and previous cropping history. Paddocks in permanent pasture were sprayed with 4 1/ha of Roundup ${ }^{\circledR}$ herbicide (1.44 kg glyphosate/ha) 
before ploughing and power-harrowing, while those in maize stubble were power-harrowed before rollerdrilling on 22 May 2000 with Bronsyn ryegrass (18 $\mathrm{kg} / \mathrm{ha}$ ) and a 50:50 mixture of Sustain and Aran white clover (Trifolium repens) (3 kg/ha) seed, followed by harrowing and rolling. The Bronsyn ryegrass was infected with wild endophyte (farmlet 1) or AR1 endophyte (farmlet 2). All pastures received $7 \mathrm{~kg} / \mathrm{ha}$ Drisan $(70 \mathrm{~g} / \mathrm{kg}$ isazophos) insecticide on 22 May 2000 for the control of black beetle. Maintenance and nitrogen fertiliser was applied equally across both farmlets in all years.

\section{Cows}

Farmlets were rotationally grazed by self-contained herds of spring-calving mixed-aged Holstein-Friesian cows from late September 2000 to early May 2003. Initially, cows were randomly allocated to farmlets balanced for age, calving date, liveweight and milksolids production. Each farmlet was stocked with 18 mixed-aged cows in 2000/2001 (included 4 heifers) and 21 cows in 2001/2002 (included 3 heifers) and 2002/2003 (included 4 heifers). Cows remained on their farmlets between milking seasons, except for those culled, which were replaced with heifers and similar cows.

\section{Management}

Each farmlet was managed as a self-contained system using decision rules developed from previous farm systems trials at Dexcel (Macdonald \& Penno 1998). These rules defined grazing management, timing and amount of conservation, feeding of pasture silage and individual cow and herd drying-off dates. No additional feed was purchased. Cows on both farmlets received $3 \mathrm{~kg} \mathrm{DM} /$ cow/day pasture silage (from the farmlet where it was made) from 4 July to 25 July 2002 because of low farmlet pasture covers (Table 1).

\section{Cow measurements}

\section{Milksolids production and milk composition}

Milksolids (MS) production (protein yield + fat yield) and milk composition (protein, fat and lactose \%) for each cow were measured weekly throughout the season. Milk yields (am/pm in 2000/2001 and 2001/ 2002 , and $\mathrm{pm} / \mathrm{am}$ in 2002/2003) were recorded using in-line milk meters and milk composition was determined using the Milkoscan FT120 milk analyser (Foss Electric, Denmark).

Incidence of ryegrass staggers, heat stress symptoms and blood plasma prolactin concentration

Cows were scored for severity of ryegrass staggers once every 3 weeks on a standard $0-5$ scale $(0=$ no staggers, $5=$ cow unable to stand: adapted from Keogh 1973) throughout the season. Scores were given to individual cows after rapid movement around the paddock for about five minutes.

During January, February 2001, and January, February and March 2002 cows were assessed for heat stress symptoms. Half the cows were fitted with progesterone-free CIDR-mounted temperature loggers to record internal body temperature every 10 minutes for at least 5 consecutive days (Bluett et al. 2000). Respiration rate was also recorded before afternoon milking on 3 consecutive days by counting the frequency of rib movements for 30 seconds using a timer with an audible alarm. Two independent, consecutive observations were averaged for each cow (Bluett et al. 2000).

Blood plasma prolactin was measured on 3 consecutive days during January and February 2001 (Bluett et al. 2003) and monthly from November 2001 to March 2002. Blood samples were collected by venipuncture of the coccygeal vein in the tail of each cow into ethylene diamine tetraacetic acid (EDTA) vacutainers before afternoon milking. Blood samples were chilled immediately then centrifuged and analysed for plasma prolactin concentration by radioimmunoassay (Prolactin Antigen and Antiserum kit; National Institute of Diabetes and Digestive and Kidney Diseases, Maryland, United States) as described by Pearson et al. (1996). The inter-assay and intra-assay coefficients of variation for samples collected in January and February 2001 were 2.6 and $11.0 \%$ (at a control concentration of $25 \mathrm{ng} / \mathrm{ml}$ ) and from November 2001 to March 2002 were 14.1 and $11.4 \%$, respectively.

\section{Pasture measurements}

\section{Pasture production, farmlet pasture cover and silage} conservation

Pasture production was estimated from September 2000 to September 2002 using two $0.5 \mathrm{~m}^{2}$ exclosure cages randomly placed in each paddock (14 cages/ treatment). The herbage within each cage was trimmed to a height of $2 \mathrm{~cm}$ using electric shears. After approximately 30 days regrowth, a $0.2 \mathrm{~m}^{2}$ quadrat within each cage was cut to $2 \mathrm{~cm}$, and then the cage was relocated nearby. The cut herbage was dried at $95{ }^{\circ} \mathrm{C}$ for $36 \mathrm{~h}$ before weighing. Farmlet pasture cover was determined weekly. Ten $0.33 \mathrm{~m}^{2}$ quadrats representing a range of pasture covers $(6$ pre-grazing and 4 post-grazing) were visually assessed and then cut to ground level using electric shears, washed and oven dried at $95^{\circ} \mathrm{C}$ for $36 \mathrm{~h}$ before weighing. All farmlet paddocks were then visually assessed and then calibrated against the herbage cuts. The quantity of 
Table 1 Average seasonal pasture cover ( $\mathrm{kg} \mathrm{DM} / \mathrm{ha}$ ) for farmlets sown in perennial ryegrass infected with AR1 or wild endophyte under rotational grazing with dairy cows over 3 years in the Waikato.

\begin{tabular}{lccccc}
\hline Year & Treatment & Winter & Spring & Summer & Autumn \\
\hline \multirow{2}{2000/2001}{} & AR1 & - & 3200 & 3100 & 3000 \\
\multirow{2}{*}{$2001 / 2002$} & Wild & - & 3300 & 3100 & 2900 \\
& AR1 & 2500 & 2900 & 3000 & 2300 \\
$2002 / 2003$ & Wild & 2600 & 2900 & 3000 & 2500 \\
& AR1 & 1800 & 2600 & 3300 & 2800 \\
& Wild & 1900 & 2700 & 3400 & 2900 \\
\hline \multicolumn{2}{l}{ Winter: June, July, Aug; spring: Sep, Oct, Nov; summer: Dec, Jan, Feb; autumn: March, April, May. }
\end{tabular}

Table 2 Mean days in milk, milk production, milk composition and milksolids production from cows grazing perennial ryegrass pasture infected with AR1 or wild endophyte over 3 milking seasons in the Waikato.

\begin{tabular}{|c|c|c|c|c|}
\hline Season & AR1 & Wild & SED & Significance $^{b}$ \\
\hline \multicolumn{5}{|l|}{$2000 / 2001$} \\
\hline Days in milk ${ }^{a}$ & 210 & 205 & 2.9 & $\dagger$ \\
\hline Milk (kg/cow) & 3335 & 2987 & 150.5 & \\
\hline Milk fat composition (\%) & 4.15 & 4.21 & 0.162 & NS \\
\hline Milk protein composition (\%) & 3.33 & 3.32 & 0.073 & NS \\
\hline Milksolids (kg/cow) & 247 & 224 & 8.4 & 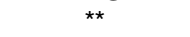 \\
\hline \multicolumn{5}{|l|}{$2001 / 2002$} \\
\hline Days in milk & 244 & 244 & 7.0 & NS \\
\hline Milk (kg/cow) & 3957 & 3806 & 151.9 & NS \\
\hline Milk fat composition (\%) & 4.25 & 4.24 & 0.131 & NS \\
\hline Milk protein composition (\%) & 3.35 & 3.31 & 0.063 & NS \\
\hline Milksolids (kg/cow) & 300 & 287 & 11.2 & NS \\
\hline \multicolumn{5}{|l|}{$2002 / 2003$} \\
\hline Days in milk & 270 & 266 & 6.0 & NS \\
\hline Milk (kg/cow) & 5056 & 4776 & 179.9 & NS \\
\hline Milk fat composition (\%) & 4.56 & 4.42 & 0.123 & NS \\
\hline Milk protein composition (\%) & 3.55 & 3.53 & 0.062 & NS \\
\hline Milksolids (kg/cow) & 404 & 379 & 14.9 & NS \\
\hline
\end{tabular}

${ }^{a}$ Cows were initially allocated to farmlets on 21 September 2000 so this season is incomplete.

${ }^{\mathrm{b}} \mathrm{NS}=$ not significant, $, \dagger=\mathrm{P}<0.1,{ }^{*}=\mathrm{P}<0.05,{ }^{* *}=\mathrm{P}<0.01,{ }^{* *}=\mathrm{P}<0.001$

Table 3 Combined analysis of seasonal milk and milksolids production from cows grazing perennial ryegrass pasture infected with AR1 or wild endophyte in the Waikato (mean of 3 milking seasons). Means produced in this table will not necessarily be the same as the mean of the three seasons analysed individually (Table 1) because the combined analysis adjusts for cows not present for all three seasons. Similarly, total milk and milksolids may not necessarily be equal to the sum of the milk and milksolids from spring, summer and autumn.

\begin{tabular}{|c|c|c|c|c|}
\hline Season & AR1 & Wild & SED & Significance ${ }^{b}$ \\
\hline \multicolumn{5}{|l|}{ Spring } \\
\hline Milk (kg/cow) & 2058 & 1949 & 78.9 & NS \\
\hline Milksolids (kg/cow) & 157 & 147 & 5.5 & $\dagger$ \\
\hline \multicolumn{5}{|l|}{ Summer } \\
\hline Milk (kg/cow) & 1465 & 1347 & 43.7 & $\star \star$ \\
\hline Milksolids (kg/cow) & 110 & 103 & 2.9 & ** \\
\hline \multicolumn{5}{|l|}{ Autumn } \\
\hline Milk (kg/cow) & 613 & 530 & 25.4 & ** \\
\hline Milksolids (kg/cow) & 50 & 44 & 2.1 & ** \\
\hline \multicolumn{5}{|l|}{ Total } \\
\hline Milk (kg/cow) & 4136 & 3801 & 133.6 & * \\
\hline Milksolids (kg/cow) & 318 & 292 & 9.2 & ** \\
\hline
\end{tabular}


pasture silage conserved in each season was recorded. Individual silage bales were weighed from each paddock. Before baling, samples of wilted pasture were collected from each paddock to determine dry matter content. Three sub-samples of pasture were weighed, oven dried at $95^{\circ} \mathrm{C}$ for $36 \mathrm{~h}$ before weighing.

\section{Endophyte infection level and tiller density}

Endophyte infection was determined in October 2000, April and September 2001, March 2002 and April 2003 from 40 random tillers cut to ground level per paddock and using the immunoblot procedure outlined by Gwinn et al. (1991). Tiller population density was calculated from 12 randomly placed $5 \mathrm{x}$ $20 \mathrm{~cm}$ tiller frames per paddock in August and October 2000, January, April and September 2001, January and April 2002 and April 2003, where the number of perennial ryegrass tillers, other grass tillers, weeds and clover growing points were recorded.

\section{Pre-grazing botanical composition, pasture quality and alkaloid concentration}

Two pre-grazing herbage samples per treatment were collected fortnightly from the next two paddocks to be grazed in the rotation. Ten $1 \mathrm{~m}$ strips of herbage were cut to ground level and bulked on a paddock basis. A $50 \mathrm{~g}$ sub-sample of pasture was dissected into ryegrass, white clover, other grasses, weeds and dead material, before oven drying at $95^{\circ} \mathrm{C}$ for $36 \mathrm{~h}$ and weighing. Sub-samples (100 g each) of whole pasture and perennial ryegrass were frozen at $-20^{\circ} \mathrm{C}$, freeze-dried and ground to pass through a $1 \mathrm{~mm}$ sieve. The whole pasture sample was analysed for estimates of quality (organic matter digestibility, crude protein and neutral detergent fibre) using near infra-red spectroscopy (NIRS) (Corson et al. 1999) and the ryegrass-only sample was analysed for alkaloid concentration (lolitrem B, ergovaline and peramine) using HPLC (Barker et al. 1993).

\section{Statistical analysis}

Cow data were analysed using Residual Maximum Likelihood (REML) in GenStat (Release 6.1) using cow to cow variation to test for treatment differences. The combined analysis of 3 seasons data was carried out using REML including age group (heifers versus cows) and herd as a fixed effect and cow as a random effect. Means of milk production data were calculated for herds comprising 20\% heifers for consistency (proportion of heifers changed slightly from year to year). Means produced from the combined analysis will not necessarily be the same as the mean of the three seasons analysed individually, because the analysis adjusts for cows not present for all 3 seasons. Similarly, total milksolids may not necessarily be equal to the sum of the milksolids from individual seasons (spring, summer and autumn). Pasture data were analysed using REML. Botanical composition was analysed using raw data and after an angular transformation, but as the conclusions were similar, the raw data are presented.

\section{Results \\ Milk production and composition}

In the first milking season (2000/2001), cows grazing AR1 endophyte-infected ryegrass produced on average $10 \%$ more MS $(\mathrm{P}<0.01)$ than those on wild endophyte-infected ryegrass (Table 2 ). In the second and third milking seasons, the treatment differences declined to $5 \%$ and $7 \%$, respectively, and were not statistically significant. Milk composition was not affected by ryegrass endophyte in all milking seasons (Table 2). In a combined statistical analysis over all seasons, cows grazing AR1 endophyte-infected perennial ryegrass on average produced more milksolids than those grazing wild endophyte-infected ryegrass (Table 3 ).

\section{Incidence of ryegrass staggers, heat stress and} plasma prolactin concentration

Ryegrass staggers occurred in 12 out of the 18 cows grazing wild endophyte-infected ryegrass in January 2001 (scores between 0.5 and 3.5), with no further effects. No ryegrass staggers occurred in any cows grazing AR1 endophyte-infected ryegrass pasture. Respiration rates were similar between treatments, except during March 2002, when cows grazing wild endophyte-infected pastures had higher respiration rates than those grazing AR1 endophyte-infected pastures (76 versus 65 breaths/minute, $\mathrm{SED}=4.7$, $\mathrm{P}<0.05$ ). During all summer measurement periods, cows grazing AR1 and wild endophyte-infected perennial ryegrass had similar mean body temperatures $\left(38.6\right.$ versus $38.6{ }^{\circ} \mathrm{C}, \mathrm{SED}=0.039$, NS), mean maximum temperatures (39.3 versus 39.4 ${ }^{\circ} \mathrm{C}$, SED $=0.079$, NS) and mean minimum temperatures $\left(38.0\right.$ versus $37.9{ }^{\circ} \mathrm{C}, \mathrm{SED}=0.138$, NS). Cows grazing AR1 endophyte-infected ryegrass had higher plasma prolactin concentrations than those grazing wild endophyte-infected ryegrass in February 2001 ( 25 versus $14 \mathrm{ng} / \mathrm{ml}, \mathrm{SED}=2.7$, $\mathrm{P}<0.001$ ) and January 2002 (43 versus $21 \mathrm{ng} / \mathrm{ml}$, $\mathrm{SED}=6.3, \mathrm{P}<0.001)($ Figure 1$)$.

\section{Pasture production, farmlet pasture cover and} silage conservation

Annual pasture production was similar across AR1 
and wild endophyte-infected perennial ryegrass farmlets from September 2000 to September 2001 (14.7 versus 14.4t DM/ha, $\mathrm{SED}=1.11$, NS) and September 2001 to September $2002(14.1$ versus $12.9 \mathrm{t} \mathrm{DM} / \mathrm{ha}, \mathrm{SED}=0.73$, NS). Average farmlet pasture cover was also similar between treatments in all seasons (Table 1). Silage conserved on the AR1 and wild endophyte-infected perennial ryegrass farmlets was approximately 2300 and $1850 \mathrm{~kg} \mathrm{DM} / \mathrm{ha}$, 550 and $350 \mathrm{~kg} \mathrm{DM} / \mathrm{ha}$ and 300 and $900 \mathrm{~kg} \mathrm{DM} / \mathrm{ha}$, in the $2000 /$ $2001,2001 / 2002$ and 2002/2003 seasons, respectively.

\section{Endophyte infection level and tiller density}

Endophyte infection level was consistently high at each sampling date in the AR1 and wild endophyteinfected pastures (mean of 96 versus $98 \%$ of tillers infected). Perennial ryegrass tiller density measured soon after establishment on 14 August 2000, was similar for AR1 and wild endophyte trea tments (2419 versus 2185 tillers $\left./ \mathrm{m}^{2}, \mathrm{SED}=360.7, \mathrm{NS}\right)$, and at all other measurement dates (mean over trial was 3243 versus 3203 tillers $/ \mathrm{m}^{2}$, SED $=242.2$, NS), as was clover growing point density (mean over trial was 285 versus 246 growing points $/ \mathrm{m}^{2}, \mathrm{SED}=56.0, \mathrm{NS}$ ).

Pre-grazing botanical composition, pasture quality and alkaloid concentration

The mean botanical composition of pre-grazing pasture samples collected each season from AR1 and wild endophyte-infected pastures were similar, except for a slightly higher white clover content in the AR1 endophyte pastures in 2000/2001 (9 versus $6 \%$ of $\mathrm{DM}, \mathrm{SED}=1.4, \mathrm{P}<0.05)$. Organic matter digestibility, crude protein and neutral detergent fibre contents of pre-grazing pasture samples were similar between treatments in all seasons. Seasonal trends in alkaloid concentrations are shown in Figure 2. Mean concentrations of peramine were slightly lower in the AR1 endophyte-infected ryegrass pastures than in the wild endophyte-infected ryegrass pastures in 2001/ 2002 (21.9 versus $24.1 \mathrm{mg} / \mathrm{kg}, \mathrm{SED}=0.67, \mathrm{P}<0.01)$ and $2002 / 2003(22.8$ versus $28.0 \mathrm{mg} / \mathrm{kg}, \mathrm{SED}=1.30$, $\mathrm{P}<0.01)$. Concentrations of lolitrem $\mathrm{B}$ and ergovaline in the AR1 endophyte-infected ryegrass pastures remained below $0.1 \mathrm{mg} / \mathrm{kg}$ and usually below a detection limit of $0.05 \mathrm{mg} / \mathrm{kg}$ (Figure 2).
Mean plasma prolactin concentration in cows grazing perennial ryegrass pasture infected with AR1 or wild endophyte in the second season from November 2001 to March 2002 (vertical ars indicate SED).

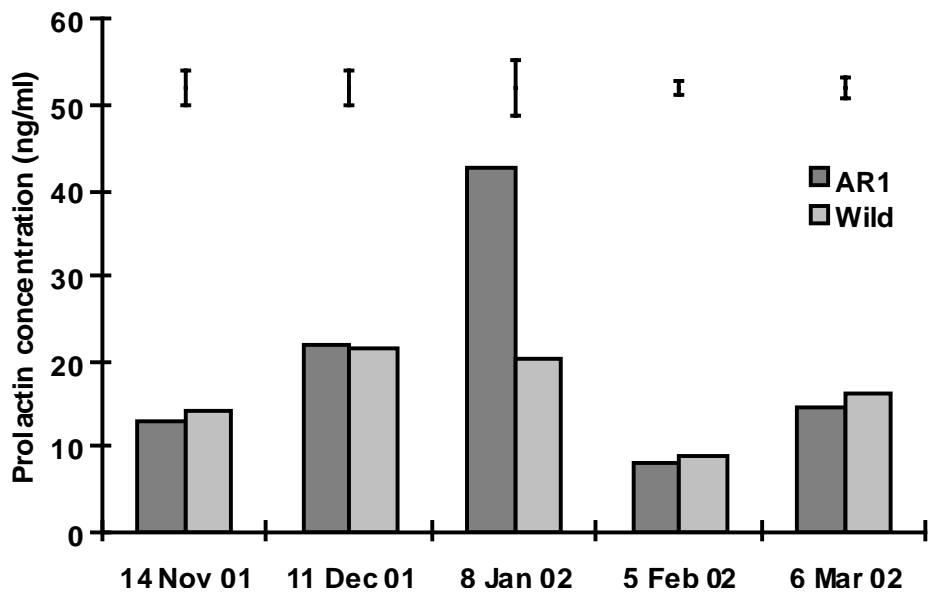

\section{Discussion}

Cows grazing AR1 endophyte-infected ryegrass produced $8.9 \%$ more milksolids than those grazing wild endophyte-infected ryegrass (combined analysis: Table 3). Thom et al. (1999) has reported small and inconsistent reductions $(<6 \%)$ in milk production due to wild endophyte in 3 out of 13 short-term tests in the Waikato. The difference in milksolids production suggests that cows grazing AR1 endophyte-infected ryegrass had a higher herbage intake than those grazing wild endophyte-infected ryegrass. As pasture production was similar across farmlets, cows grazing AR1 endophyte-infected ryegrass may have better utilised the pasture, but this can not be determined from the current experiment. Liveweight and condition scores were similar in cows grazing AR1 and wild endophyte-infected pastures over the three years (Bluett unpublished data). The magnitude of the milksolids response varied over the 3 seasons, with the largest treatment difference in milksolids occurring in 2000/2001 (Table 2). However, it should be noted that this season was incomplete due to cows being allocated to farmlets in late September, which may have magnified the total difference in milksolids production compared with the subsequent seasons, which had longer spring periods when alkaloid concentrations were lower.

Reduced plasma prolactin concentration, increased body temperature and increased respiration rate have been consistent responses in sheep while grazing wild endophyte-infected perennial ryegrass, especially in hot weather (Fletcher et al. 1999). However, on only 1 out of 5 measurement dates in the 2001/2002 season was plasma prolactin concentration lower in cows 
grazing wild endophyte-infected pastures (Figure 1). Bluett et al. (2003) also reported that the effect of wild endophyte on plasma prolactin concentration in dairy cows was small and variable over the milking season. On occasions, cows from both the AR1 and wild endophyte-infected ryegrass farmlets showed open-mouth breathing and excessive salivation, which according to Davidson et al. (1996) are symptoms of extreme heat load caused by high air temperatures and relative humidity. However, mean cow temperature and respiration rates were similar between treatments on most measurement dates in this experiment. This shows that sheep and dairy cows respond differently to wild endophyte possibly because of differences in grazing management, grazing behaviour or sensitivity to alkaloids. For example, dairy cows are moved more frequently to fresh pastures than sheep and are therefore less likely to be forced to graze into the base of the sward where ergovaline concentrations are typically highest (Lane et al. 1997). On few occasions in this study was the consumption of ergovaline by cows grazing wild endophyte-infected pastures high enough to depress serum prolactin levels, increase respiration rates or cow temperatures.

Alkaloid concentrations in wild endophyte-infected pastures were lowest in spring and increased with rising temperatures and ryegrass reproductive development (Easton 1999). Ryegrass staggers occurred in cows grazing wild endophyte-infected pastures in January 2001 only, coinciding with the highest concentrations of lolitrem B over the 3 seasons $(>3.5 \mathrm{mg} / \mathrm{kg}$ : Figure 2). This variation in lolitrem B concentration between seasons reflects differences in environmental conditions, such as water stress (Easton 1999).

Annual pasture production was similar across AR1 and wild endophyte-infected ryegrass farmlets in the first two years after establishment confirming other work (Bluett et al. 2001b; Bluett unpublished data). There was also no difference in ryegrass tiller density on any measurement date over the experiment. Popay
Figure 2 Mean alkaloid concentration: (a) Lolitrem B; (b) Ergovaline, (c) Peramine in rotationally grazed perennial ryegrass pastures infected with AR1 (-O-) or wild endophyte (-O-) over 3 seasons in the Waikato.
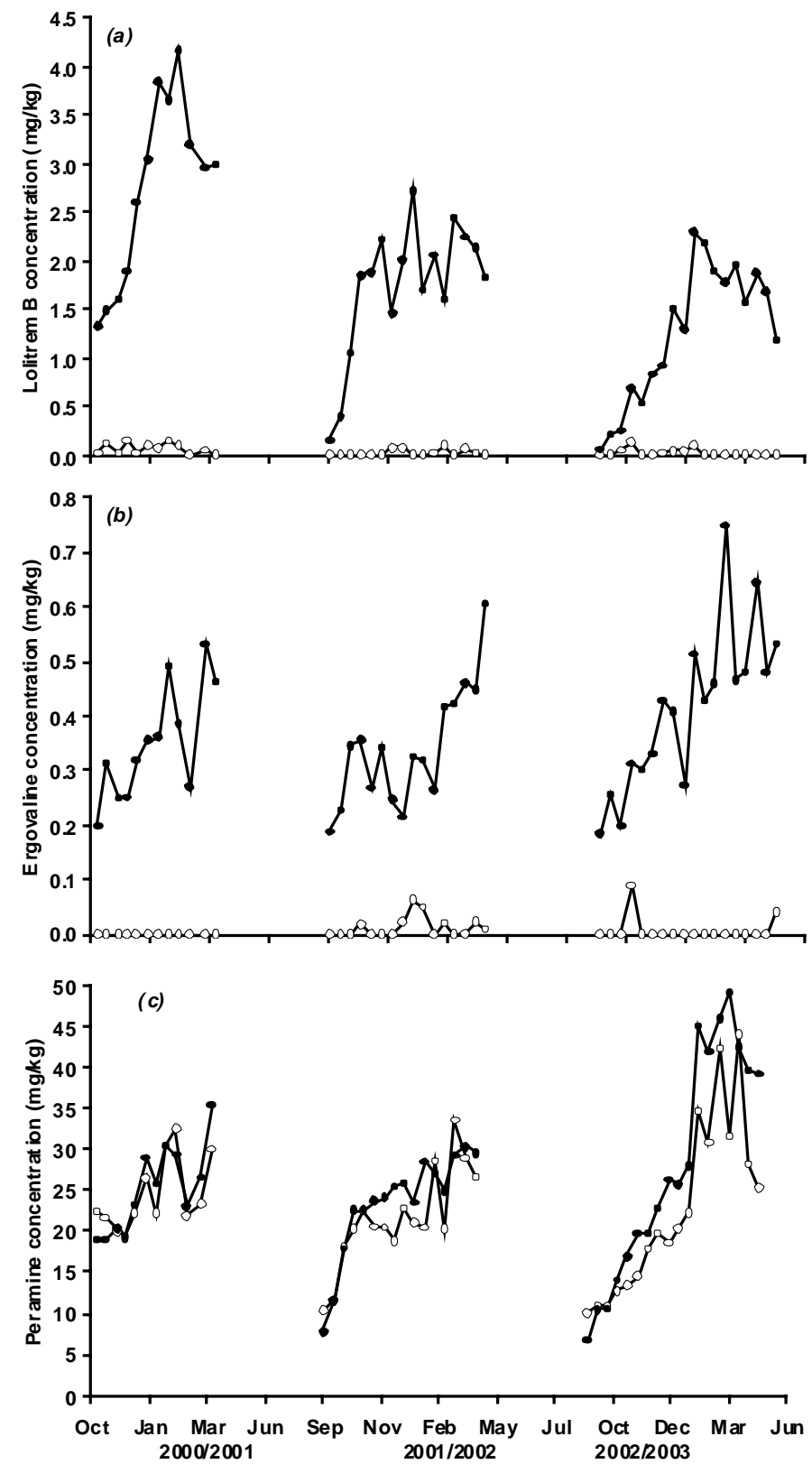

\& Baltus (2001) have demonstrated that ryegrass seedlings infected with AR1 are more susceptible to black beetle damage than ryegrass infected with wild endophyte. As a result, insecticide was applied soon after establishment in the current experiment. However, this may have reduced the chances of pasture production differences occurring as a 
consequence of seedling damage by black beetle. Peramine concentrations were high in both the AR1 and wild endophyte-infected ryegrass pastures and usually greater than $15 \mathrm{mg} / \mathrm{kg}$ (Figure 2), the threshold needed to deter feeding by adult and larval Argentine stem weevil in spring and summer (Popay \& Wyatt 1995).

Lolitrem B and ergovaline concentrations in all 3 seasons were almost undetectable in the AR1 endophyte-infected perennial ryegrass pasture (Figure 2 ), indicating that this farmlet was not contaminated by wild endophyte-infected ryegrass. This finding was also confirmed from an analysis of 100 individual perennial ryegrass tillers per paddock for lolitrem B presence, with only 4 out of 700 tillers collected from the AR1 endophyte farmlet identified as being infected with wild endophyte (Bluett unpublished data). Spray/cultivation or cropping the summer before sowing was used in the current experiment, both of which have been shown by Bluett et al. (2001a) to be effective methods for minimising contamination. Also, farmlets were self-contained and only cows in the AR1 endophyte treatment grazed the AR1 farmlet. This prevented the transfer of wild endophyte-infected ryegrass seed in dung from cows grazing pastures infected with wild endophyte (Burggraaf \& Thom 2000).

Results from this experiment show that sowing a whole farm in perennial ryegrass infected with AR1 endophyte can increase milksolids production over one sown in the same cultivar infected with the standard wild endophyte. Most farmers would have only a small portion of their farm regrassed with AR1 endophyte-infected ryegrass, and this pasture would provide safe feed for stock affected by ryegrass staggers. Ongoing management is required to prevent the reintroduction of wild endophyte-infected ryegrass into AR1 endophyte-infected ryegrass pastures. A withholding period of 2-3 days is recommended by Burggraaf \& Thom (2002) after cows graze wild endophyte-infected ryegrass pastures with mature seedheads (December until April) to prevent the transfer of ryegrass seed in cow dung. During this withholding period, cows could be grazed on an alternative forage crop. Alternatively, wild endophyteinfected ryegrass pastures could be mown before grazing to remove seedheads. Hay cut from wild endophyte-infected ryegrass should not be fed out on AR1 endophyte-infected ryegrass pastures to avoid introducing seed containing wild endophyte.

\section{Conclusions}

This farmlet experiment showed pasture production was similar regardless of ryegrass endophyte type.
In a combined analysis of 3 seasons data, cows grazing AR1 endophyte-infected ryegrass produced $8.9 \%$ more total milksolids than those grazing the standard wild endophyte, without any incidence of ryegrass staggers. AR1 endophyte-infected ryegrass pastures remained free of contamination from wild endophyte-infected ryegrass plants for at least 3 years after establishment.

\section{ACKNOWLEDGEMENTS}

AGMARDT and FRST funded this research. The authors wish to thank the staff at Scott farm, Deanne Waugh, Rachael Chatham, Rodger Jensen, Kara White, Joe Day, Liz Grayling, Vicki Burggraaf, Helen Simons, Neil Davidson, Anita Sutton, David Porter, Julia Lee, Stuart van Vugt and Glenise Ferguson for technical assistance (Dexcel). Liz Davies, Brian Tapper and David Hume (AgResearch, Grasslands) are gratefully acknowledged for the alkaloid analysis, Lee Davies (AgResearch, Ruakura) for endophyte testing, Andrew Fisher (AgResearch, Ruakura) for assistance with recording cow temperatures, Carol Leydon-Davis and Jim Lancaster for collection of cow data (Dexcel) and Barbara Dow for statistical analysis.

\section{REFERENCES}

Barker, D. J.; Davies, D.; Lane, G. A.; Latch, G. C. M.; Nott,H. M.; Tapper, B. A. 1993. Effect of water deficit on alkaloid concentrations in perennial ryegrass endophyte associations. pp. 67-71. In: Proceedings of the Second International Symposium on Acremonium/Grass Interactions. Eds. Hume, D. E.; Latch, G. C. M.; Easton, H. S. Palmerston North, AgResearch Grasslands, Palmerston North.

Bluett, S. J.; Burggraaf, V. T.; Hume, D. E.; Tapper, B. A.; Thom, E. R. 2001a. Establishment of ryegrass pastures containing a novel endophyte. Proceedings of the New Zealand Grassland Association 63: 256-265.

Bluett, S. J.; Fisher, A. D.; Waugh, C. D. 2000. Heat challenge of dairy cows in the Waikato: a comparison of spring and summer. Proceedings of the New Zealand Society of Animal Production 60: 226-229.

Bluett, S. J.; Kolver, E. S.; Auldist, M. J.; Thom, E. R.; Davis, S. R.; Farr, V. C.; Tapper, B. A. 2003. Perennial ryegrass endophyte effects on plasma prolactin concentration in dairy cows. New Zealand Journal of Agricultural Research 46: 9-14.

Bluett, S. J.; Thom, E. R.; Clark, D. A.; Tapper, B. A. 2001b. Milk production and composition from cows grazing perennial ryegrass infected with a novel endophyte. pp. 195-199. In: Proceedings of the 
Fourth International Symposium on Neotyphodium/ Grass Interactions. Eds. Paul, V. H.; Dapprich, P. D. Burggraaf, V. T.; Thom, E. R. 2000. Contamination and persistence of endophyte-free ryegrass pastures established by spray-drilling, and intensively grazed by dairy cows in the Waikato region of New Zealand. New Zealand Journal of Agricultural Research 43: 163-173.

Burggraaf, V. T.; Thom, E. R. 2002. Minimising endophyte contamination from ryegrass seed in cow dung. Proceedings of the New Zealand Grassland Association 64: 97-101.

Corson, D. C.; Waghorn, G. C.; Ulyatt, M. J.; Lee J. 1999. NIRS: Forage analysis and livestock feeding. Proceedings of the New Zealand Grassland Association 61: 127-132.

Davison, T.; McGowan, M.; Mayer, D.; Young, B.; Jonsson, N.; Hall, A.; Matschoss, A.; Goodwin, P.; Goughan, J.; Lake, M. 1996. In: Managing hot cows in Australia. Department of Primary Industries, Queensland, Australia.

Easton, H. S. 1999. Endophyte in New Zealand ryegrass pastures, an overview. Grassland Research and Practice Series 7: 1-9.

Fletcher, L. R. 1999. "Non-toxic" endophytes in ryegrass and their effect on livestock health and production. Ryegrass endophyte: an essential New Zealand symbiosis. Grassland Research and Practice Series 7: 133-139.

Fletcher, L. R.; Suther land, B. L.; Fletcher, C. G. 1999. The impact of endophyte on the health and productivity of sheep grazing ryegrass-based pastures. Grassland Research and Practice Series 7: 11-17. Gwinn, K. D.; Collins-Shepard, M. H.; Reddick, B. B. 1991. Tissue print-immunoblot, an accurate method for the detection of Acremonium coenophialum in tall fescue. Phytopathology 81 : 747-748.

Keogh, R. G. 1973. Induction and prevention of ryegrass staggers in grazing sheep. New Zealand Journal of Experimental Agriculture 1: 55-57.

Lane, G. A.; Ball, O. J. P.; Davies, E.; Davidson, C. 1997. Ergovaline distribution in perennial ryegrass naturally infected with endophyte. pp. 65-67. In: Neotyphodium/grass interactions. Eds. Bacon, C. W.; Hill, N. S. Plenum Press, New York.

Macdonald, K. A.; Penno, J. W. 1998. Management decision rules to optimise milksolids production on dairy farms. Proceedings of the New Zealand Society of Animal Production 58: 132-135.

Pearson, A. J.; Parry, A. L.; Ashby, M. G.; Choy, V. J.; Wildermoth, J. E.; Craven, A. J. 1996. Inhibitory effect of increased photoperiod on wool follicle growth. Journal of Endocrinology 148: 157-166.

Popay, A. J.; Baltus, J. G. 2001. Black beetle damage to perennial ryegrass infected with AR1 endophyte. Proceedings of the New Zealand Grassland Association 63: 259-265.

Popay, A.J.; Wyatt, R.T. 1995. Resistance to Argentine stem weevil in perennial ryegrass infected with endophytes producing different alkaloids. Proceedings of the New Zealand Plant Protection Conference 48: 229-236.

Tapper, B. A.; Latch, G. C. M. 1999. Selection a gainst toxin production in endophyte-infected perennial ryegrass. Ryegrass endophyte: an essential New Zealand symbiosis. Grassland Research and Practice Series 7: 107-111.

Thom, E. R.; Clark, D. A.; Waugh, C. D. 1999. Endophyte and dairy production in New Zealand: experience at the Dairying Research Corporation. Grassland Research and Practice Series 7: 39-44. 